\title{
The Tragedy of Kashmir: An Interpretation of Vishal Bhardwaj's film Haider (2014) and Basharat Peer's memoir Curfewed Night (2008)
}

\author{
${ }^{1}$ Sanchari Basak, ${ }^{2}$ Ankita Ghosh \\ ${ }^{1}$ State Aided College Teacher (Category-I), Banipur Mahila Mahavidyalaya, West Bengal \\ ${ }^{2}$ Student of B.Ed, Lokenath B.Ed. College, West Bengal \\ DOI: 10.29322/IJSRP.11.01.2021.p10996 \\ http://dx.doi.org/10.29322/IJSRP.11.01.2021.p10996
}

\begin{abstract}
Vishal Bhardwaj's film Haider(2014) reproduces Shakespeare's Hamlet amidst the insurgencies and civilian disappearances that affected the 1990s in Kashmir, a region over which India and Pakistan have fought since Partition in 1947. Basharat Peer, the screenwriter and the author of the book Curfewed Night (2008) transforms the tragedy of a single individual into the collective tragedy of an entire region. Unlike Bollywood traditional representations of Kashmir as a romantic place for lovers, the film depicts a politically volatile land in which early mornings are marked by crackdowns, fathers are separated from their families and made to disappear, young men are tortured and killed without any apparent reason, mothers are condemned to spend the rest of their lives searching for their disappeared sons. In this paper I will examine how the entire community of Kashmir of that time was reduced to a state deprived of their basic human rights through the lens of Haider and Peer's memoir. The common folk of Kashmir constantly thrives to get their freedom back. The right to determine the destiny of their own territory was denied to them by the political apparatus. Obviously it posits a question to the concept of democracy. The arbitrary state of violence leading to the traumatic experience of the Kashmiris producing psychological disorders evokes the necessity of this study.
\end{abstract}

Keywords: Film adaptation, Kashmir, democracy, freedom, degradation, fear, Constitution

\section{Introduction}

In Indian popular culture, Kashmir used to be seen as a paradise on earth: its 'idyllic beauty and lyrical scenery' have inspired poets and artists, and the traditional association of its picturesque landscape with romantic love has frequently been exploited by Mumbai's film industry. Most of the evergreen romantic numbers in the Bollywood albums of the golden era of Indian Cinema were picturized on the blissful moments of love in the snow-clad and lush green locales of Jammu \& Kashmir in different seasons of the year. Bollywood's 'most exotic colony' used to be perceived as an eroticised territory, as a place for lovers and honeymoons, a sort of 'Switzerland of India'. Moreover, its being a symbol of pure and unspoiled nature has often acted as a 'visual therapy for audiences coping with life in overcrowded cities and towns' (Sarkar 37-38).

Kashmiri composite culture, which blended Hindu and Islamic traditions, used to be referred to as Kashmiriyat: 'it weaved the strong fabric of Hindu-Muslim bonding, communal harmony and socio-religious co-existence'. This Hindu-Muslim balance, however, was broken in course of time by greed for power, so that Kashmir has now become a perpetual battleground even in religious terms, the place of political contention between India and Pakistan, both claiming the legal ownership of the region (Deshmukh 1). Hence, the whole area has been militarized and subjected to political repression to the point of drowning in an arbitrary state of violence (Mookherjee 3).

Vishal Bhardwaj's screen adaptation Haider(2014) reproduces Shakespeare's Hamlet by transposing its setting from late-Medieval "rotten" Denmark to the embattled Kashmir of 1995, a region over which both India and Pakistan have fought since Partition in 1947. The first half of the film attempts to set the scene against this political backdrop, while the Shakespearean plot is developed mainly in the second half. The choice of setting Haider in Kashmir in 1995 is explained by the director in the preface to the original screenplay. After having found his wife Rekha crying in the middle of the night while reading Basharat Peer's memoir Curfewed Night (2008), Bhardwaj decided to read the reporter's memoir himself. After reading the book he was so moved that he abandoned his initial plan of adapting Hamlet into an espionage thriller involving the 'Research and Analysis Wing' (R\&AW) and to rather opt for a story in the tormented region of Kashmir, firmly believing that 'Kashmir has been the biggest tragedy of modern Indian history' and that no film has been made to really capture it. The collaboration with Peer ensued spontaneously: Haider thus departs from being a 'mere' spy thriller and instead underpins a tragedy of the whole community, focusing especially on the idea of loss of identity. In the film, 
Kashmir is treated more than an 'inert and serviceable backdrop'. Most importantly, the playwright's work is not employed 'as a makeshift vehicle for [the region's] politics' (Sarkar 34). Rather the filmmaker aimed to comment on an anti-human situation that could not be kept hidden any further.

\section{Kashmir: A Battleground and its Inhabitants}

In 1947, when British India was divided into two independent nations, the Dominion of India and the Dominion of Pakistan, via the Indian Independence Act, Kashmir, being a native princely state, was free to either join one of the two dominions or remain independent. Later that year, Pakistani troops disguised as tribesmen attacked the region, almost obliging Maharaja Hari Singh, who wanted Kashmir to be independent in order to maintain a good relationship with both neighbouring states, to seek aid from India; also the United Nations organization was called in and asked to deal with the matter. Eventually, though under the special provisions of Article 370 of the Indian Constitution, the region was made to access India. During Indo-Pak War in 1965, the political situation of Kashmir remained relatively peaceful, and its inhabitants, who were over 90 percent Muslims, did not side with Islamic Pakistan. Militantism rose in 1989, when Hindu Kashmiris were expelled from their native land. The plausible reasons suggested for this emergence of insurgency include a lack of adequate opportunities for Kashmiri youths, some political decisions taken by the central government of India, and the meddling of Pakistan in the region's affairs. As a consequence, the presence of the Indian armed forces increased in the Valley, and the Indian government instituted the Armed Forces Special Powers Act (AFSPA), which, initially introduced to tackle terrorism, ended up giving the Indian army 'the power to shoot anyone suspected of being a threat', granting officers 'immunity from prosecution in a court of law' (Peer 182). According to the special powers conferred to Indian soldiers by AFSPA, they are free to interrogate and arrest any person suspected of being linked to any militant organizations, as well as to destroy their houses. In one chilling scene of Haider a man, his face covered in a balaclava, plays judge and jury from a jeep, as civilians are paraded in front of him. With just a movement of his eyes he decides their fate: dismissed or detained (0:09:37-0:10:28).

The disproportionate number of security personnel and the disproportionate amount of power and impunity they wield under the AFSPA and other laws means that the everyday life of ordinary Kashmiris is turned into living hell. There is a bunker every few hundred metres and a camp for every few villages. There are so many security checks and so many orders to produce id proofs that the whole of Kashmir is transformed into a jail for the natives. There are regular killings, rapes, molestations, beatings and an unrelenting dose of threat to life, honour, family and property, resulting in constant fear and humiliation. To an ordinary Kashmiri, even when the security forces are not indulging themselves in their privileges, the nature and the memory of the relationship the people share with the security forces is such that in a common space the former are reduced to an inferior class, further enraging the natives who see such degradation in their own land as one of the worst possible disgraces.

\section{Display of Death and Disorder}

In Haider, the issue of losing one's personal identity is highlighted effectively in a scene where a Kashmiri man (interpreted by Basharat Peer himself) stands on the threshold of his own house without entering. Roohdaar (one of the major characters in the film) intervenes: he asks the man to show him his identity card, frisks him as Indian officers usually do, then allows him to cross the doorsill. This man is diagnosed with a pathological condition called 'New Disease', which clearly witnesses the level of juridical intervention in people's lives (1:04:14-1:05:08). This particular episode alludes to Kashmiri author Akhtar Mohiuddin's short story 'New Disease', whose copyrights were bought by the film's producers (Deshmukh 8). In Peer's memoir allusion to such psychological state is also found:

[A] man waits for a long time, as if in a queue, before entering his own house. And then runs away and leaves in another direction. His family takes him to a doctor. The doctor says, 'Ever since frisking has been introduced, a new disease has come up. Some people need to be frisked every time they see a gate; others frisk themselves.' He prescribes a 'body search' every time he reaches a gate. The family follows the prescription and the man's condition improves (165-166).

One of the most touching and shocking scenes of the film occurs in the song 'Jhelam' during Haider's search for his father: a bloodsoaked boy leaps out of a truck full of stinking, mutilated corpses and dances in jubilation, rejoicing to be alive. Just as an example of Bhardwaj's use of his sources, this is a very similar episode described by Peer:

A police truck came. The bodies were put in the truck; the police put Farooq in too. The truck moved to the police control room - it was to become the site where Kashmiris would go to collect bodies of their kin in the days to come. [...] The truck stopped at the police hospital two miles from Gawkadal. [...] a teenager, whose clothes and face were drenched in blood, jumped out of the pile of bodies. The boy ran his hands on his body and cried, 'I got no bullets. I got no bullets. I am alive.' He stood still for a moment and suddenly ran out of the police control room building(125).

Underneath the rubric of the apparent reasons of militarization with impunity are buried deeper reasons akin to a political subconscious. What Kashmiris assert through their protests is the political right of self-determination and not just the facts of human 
rights abuses. They do not merely want the removal of military and withdrawal of AFSPA and other such laws; they want complete removal of India from their land and the withdrawal of the Indian Constitution.

At the clock tower of Lal Chowk the allegedly gone-insane protagonist performs his political resistance and condemns both India and Pakistan, whose laws were distorted in such a way that they now seem to defend the oppressors rather than the oppressed (Modak and Roy 162). Such an episode represents a turning point in both film and character's mission, as Haider adds to personal revenge also the aim to oppose the larger corrupt system dictated by the Indian government and by those local politicians that are often in connivance with the Indian forces - as testified to by his uncle Khurram (Mookherjee 9). Freedom (azadi), which has already been presented in preceding scenes in the film as the street protesters' rallying cry, is what Kashmiris are asking for.

HAIDER: Hello... Hello... mic testing one, two, three hello... Can you hear me? Hello, hello, hello, hello... UN Council Resolution number 47 of 1948. Article 2 of the Geneva Convention and article 370 of the Indian constitution... raises but one question!

... Do we exist or do we not? If we do... then who we are? If not... then where are we? Do we exist at all? Or not?

...HAIDER: There is no law, there is no order. Made on order... Law and order... India! Pakistan! A game on the border. India clings to us. Pakistan leeches on... What of us? What do we want?

CROWD: Freedom!

...HAIDER: We will be free!

ALL TOGETHER: Freedom!

$(1: 26: 40-1: 28: 57)$

The young man's sufferings are indicative of the whole region's painful reality, here embodied by the crowd. The right of selfdetermination is a universally acknowledged principle. It is based in the belief that people are the best judge of their own good and their future. This belief may not be an absolute standard, but the truth is that all criticisms of the principle are self-contradicting and self-defeating. The logic of this belief becomes clear when one acknowledges that it is difficult to find individuals or people who will deny self-determination to themselves. Kashmiri inhabitants demand this right to be reserved back to them. Instances are witnessed in the film.

[This dialogue is part of a flashback. The camera lingers on a street wall, where someone wrote 'Go India Go Back'.]

HAIDER'S GRANDFATHER: God alone knows when blood will stop raining on our land.

ZAHOOR: It's all up to India. As they say in India, "birth right.” And we are only claiming our right... Freedom.

GRANDFATHER: Freedom... the lathi-holder won it even for India... not the gun-holder. The gun only knows how to avenge. Commander, if we cannot make ourselves free from this sense of revenge, we can never get true freedom. Remember, revenge only begets revenge. $(0: 52: 38-0: 53: 40)$

On another occasion, mothers and wives holding photographs of their beloved sons and husbands are filmed in silent vigil in front of the army barracks, waiting patiently (and in most cases in vain) for an answer about their men's destiny (Sen 2). In the movie, Arshia's newspaper article reads: 'Politics returns, but 8,000 still missing in Kashmir'. Peer writes:

Between 4000 and 8000 men have disappeared after being arrested by the military, paramilitary, and the police. Newspapers routinely refer to the missing men as 'disappeared persons,' and their waiting wives are the 'half-widows.' The government has refused to set up a commission of enquiry into the disappearances and claims that the missing citizens of Kashmir have joined militant groups and crossed for arms training in Pakistan. Many Kashmiris believe the 'disappeared' men were killed in custody and cremated in mass graves. Wives of many such men have given up hope and tried to move on. Others are obsessively fighting for justice, hoping their loved ones will return. The men and women in the park were the parents and wives of the missing men. Dirty wars seem to have a way of bringing mothers to city squares (135).

\section{No Man's Land}

Kashmiris have become the citizens of a "no man's land": not only are they searching for their disappeared relatives, they are also looking for their own selves, for their identity, and for a permanent peace in their land. In this regard, Deshmukh defines Kashmir as a "burning paradise carrying the relics of broken relations where people forlorn in their motherland" and just live of their fragmented memories (1-2).

This publication is licensed under Creative Commons Attribution CC BY. 
Further appalling scenes show the methods of torture used by the Indian security forces when they interrogate suspected militants or people accused of harbouring militants. These human rights abuses often result in physical disfigurement and lead to impotence, thus diminishing the prisoners' humanity and especially their masculinity (Mookherjee 6). Rendered visually by Bhardwaj, these tortures are detailed in Peer's book:

'They beat us up with guns, staffs, hands. But that was nothing.' [...] 'They took you out to the lawn outside the building. You were asked to remove all your clothes, even your underwear. They tied you to a long wooden ladder and placed it near a ditch filled with kerosene oil and red chilli powder. They raised the ladder like a seesaw and pushed your head into the ditch. It could go on for an hour, half an hour depending on their mood.' 'It was the beginning. At times, they would not undress you but tie you to the ladder. You almost felt relieved until they tied your pants near the ankles and put mice inside.' [...] 'Or they burnt your arms and legs with cigarette butts and kerosene stoves used for welding. They burn your flesh till you speak.' [...] 'They tied copper wire around your arms and gave high voltage shocks. Every hair on your body stood up. But the worst was when they inserted the copper wire into my penis and gave electric shocks. They did it with most boys. It destroyed many lives. Many could not marry after that' (147-148).

Bhardwaj renders the torture scenes symbolically in the released version of the film through Roohdaar's account to Haider. One of the places where captured Kashmiris are tortured is called MAMA-2, a detention centre that corresponds to the infamous PAPA-2 interrogation centre on the banks of the Dal Lake in Srinagar. Roohdaar narrates in the flashback that MAMA-2 was the other name for hell. Men returned from there as mere shadows of themselves. In this scene police officers are found interrogating prisoners tied up or hung and at the end a teenager utters in fear

Sir, I swear I'm a student. I swear, sir... I'm not a militant. I'm not a militant.

[In the flashback, screams are heard and tortures are shown more or less directly.] $(1: 13: 20)$

In general, it can be said that Haider does not align itself with one side or the other, as Haider's father Doctor Meer's initial hesitation in choosing one precise camp exemplifies (Mookherjee 3). Only after his arrest, the father, from being a politically neutral professional, becomes a stubborn, rebellious, and embittered prisoner.

\section{Conclusion}

'All of Kashmir is a prison', Haider says, and Bhardwaj and Peer show the toll on the inmates. Haider's madness (true or false as it may be) is not judged as a reaction to a hindered love like in Hamlet, but as the culmination of a political bind, of the trauma Haider has experienced and which is common to many Kashmiri youngsters. This trauma is heightened by the discovering of the dynamics of his father's death and by the personal uncovering of his unmarked grave (Sen 4). Hence, the protagonist's insanity may be seen as standing for the paralyzing dilemma about whether Kashmir should be a free state or rather a part of India. In terms of physical appearance, the protagonist's descent into madness is determined by his gradual transformation into a militant, which involves altering his physical features and dismissing his Westernised clothes. At the very end of the film,

Dressed in dark monochromatic clothing, with a pronounced limp, after the loss of every remaining marker of his identity - his lover and his mother - Haider is transformed into the photo negative of washed out, pale and ghostly Roohdaar (Mookherjee 8).

\section{Works cited}

1. Chakravarti, P. (2016) Haider dir. By Vishal Bhardwaj (review). Shakespeare Bulletin 34(1):129-132. Retrieved on 21 April 2020 from https://www.researchgate.net/publication/299459476 Haider_dir by Vishal Bhardwaj.

2. Deshmukh, Dr. A. S. (2016) Burning Paradise: A Comparative Study of Agha Shahid Ali's Poetry and Vishal Bhardwaj's Haider. International Journal of Multifaceted and Multilingual Studies, 3(7): 1-9. Retrieved on 12 August 2020 from https://www.scribd.com/document/396846450/Burning-Paradise-AComparative-Study-of-pdf.

3. Dutta, S. (2013) Shakespeare-wallah: Cultural Negotiation of Adaptation and Appropriation. The South Asianist, 2(3): 33-47. Retrieved on 29 May 2020 from http://www.southasianist.ed.ac.uk/article/view/292.

4. Gohar, A, et al. "Hamlet-Haider: From Rotten Denmark to Rotten Kashmir". International Journal of Multifaceted and Multilingual Studies, vol. 3, no. 7, July 2015, pp. 116-123, https://www.researchgate.net/publication/301231618_Hamlet-Haider_From_Rotten_Denmark_to_Rotten_Kashmir. Accessed 5 March 2020. Accessed 21 April 2020.

5. Bhardwaj, V. (Director). (2014). Haider. VB Pictures. Retrieved on 15 January 2019 from https://data.mymp3app.com/480-movie/haider-(2014)-hindi-fullmovie-(mymp3app.com)-(480p).mp4. 
6. Modak, P. and Roy, S. (2016) Studying Vishal Bhardwaj's Haider: A Third World Reading of Shakespeare Magnus Opus. Death Voyage, 1, (Special issue): 158-163. Retrieved on 12 August 2020 from http://www.daathvoyagejournal.com/book/issue 1_a87ff679a2f3e71d9181a67b7542122c 4.pdf.

7. Mookherjee, T. (2020). Absence and Repetition in Vishal Bhardwaj's Haider. Cogent Arts and Humanities, 1-11. Retrieved on 30 June 2020 from https://www.cogentoa.com/article/10.1080/23311983.2016.1260824.

8. Peer, B. (2014). Curfewed Night. New York: Scribner.

9. Saltz, R. (2014). Shakespearean Revenge in a Violent Kashmir. The New York Times, Retrieved on 21 April 2020 from https://www.nytimes.com/2014/10/03/movies/haider-puts-an-indian-twist-on-hamlet.html?_r=0.

10. Sarkar, A. (2017). Haider and the Nation-State: Shakespeare, Bollywood, and Kashmir. South Asian Review, 37(2): 29-46. Retrieved on 30 June 2020 from https://www.tandfonline.com/toc/rsoa20/37/2?nav=tocList.

11. Sen, A. (2019). Locating Hamlet in Kashmir: Haider, Terrorism, and Shakespearean Transmission. In S. F. Loftis, A. Kellar and L. Ulevich (eds) Shakespeare's Hamlet in an Era of Textual Exhaustion, New York: Routledge.

12. Shakespeare, W. (2016). Hamlet Revised Edition, edited by Ann Thompson \& Neil Taylor, London: Bloomsbury Arden Shakespeare.

13. Singh, H.(2014,October 5). Kashmir is the Hamlet of my film,' says Vishal Bhardwaj on Haider. The Indian Express. https://indianexpress.com/article/entertainment/bollywood/kashmir-is-the-hamlet-of-my-film/

14. TRM Editors. (2015). Decoding Shakespeare: Vishal Bhardwaj's on Haider at NYIFF. The Review Monk. http://thereviewmonk.com/article/decodingshakespeare-vishal-bhardwaj-haider-nyiff/. 